\title{
Electron Acceptor Availability Alters Carbon and Energy Metabolism in a Thermoacidophile
}

\section{Authors: Maximiliano Amenabar, Daniel R. Colman, Saroj Poudel, Eric E. Roden, and Eric S. Boyd}

This is the peer reviewed version of the following article: see citation below, which has been published in final form at https://dx.doi.org/10.1111/1462-2920.14270. This article may be used for non-commercial purposes in accordance with Wiley Terms and Conditions for Self-Archiving.

Amenabar, Maximiliano, Daniel R. Colman, Saroj Poudel, Eric E. Roden, and Eric S. Boyd. "Electron Acceptor Availability Alters Carbon and Energy Metabolism in a Thermoacidophile." Environmental Microbiology 20, no. 7 (May 2018): 2523-2537. DOI:10.1111/1462-2920.14270. 


\section{Electron acceptor availability alters carbon and energy metabolism in a thermoacidophile}

\author{
Maximiliano J. Amenabar, ${ }^{1}$ Daniel R. Colman, ${ }^{1}$ \\ Saroj Poudel, ${ }^{1}$ Eric E. Roden ${ }^{2,3}$ and Eric S. Boyd ${ }^{1,3 *}$ \\ ${ }^{1}$ Department of Microbiology and Immunology, \\ Montana State University, Bozeman, MT, USA. \\ ${ }^{2}$ Department of Geosciences, University of Wisconsin, \\ Madison, WI, USA. \\ ${ }^{3}$ NASA Astrobiology Institute, Mountain View, CA, USA.
}

\section{Summary}

The thermoacidophilic Acidianus strain DS80 displays versatility in its energy metabolism and can grow autotrophically and heterotrophically with elemental sulfur $\left(\mathrm{S}^{\circ}\right)$, ferric iron $\left(\mathrm{Fe}^{3+}\right)$ or oxygen $\left(\mathrm{O}_{2}\right)$ as electron acceptors. Here, we show that autotrophic and heterotrophic growth with $S^{\circ}$ as the electron acceptor is obligately dependent on hydrogen $\left(\mathrm{H}_{2}\right)$ as electron donor; organic substrates such as acetate can only serve as a carbon source. In contrast, organic substrates such as acetate can serve as electron donor and carbon source for $\mathrm{Fe}^{3+}$ or $\mathrm{O}_{2}$ grown cells. During growth on $\mathrm{S}^{\circ}$ or $\mathrm{Fe}^{3+}$ with $\mathrm{H}_{2}$ as an electron donor, the amount of $\mathrm{CO}_{2}$ assimilated into biomass decreased when cultures were provided with acetate. The addition of $\mathrm{CO}_{2}$ to cultures decreased the amount of acetate mineralized and assimilated and increased cell production in $\mathrm{H}_{2} / \mathrm{Fe}^{3+}$ grown cells but had no effect on $\mathrm{H}_{2} / \mathrm{S}^{\circ}$ grown cells. In acetate/ $/ \mathrm{Fe}^{3+}$ grown cells, the presence of $\mathrm{H}_{2}$ decreased the amount of acetate mineralized as $\mathrm{CO}_{2}$ in cultures compared to those without $\mathrm{H}_{2}$. These results indicate that electron acceptor availability constrains the variety of carbon sources used by this strain. Addition of $\mathrm{H}_{2}$ to cultures overcomes this limitation and alters heterotrophic metabolism.

\section{Introduction}

Hydrothermal environments can be dynamic and vary chemically or physically on time scales that range from

Received 24 May, 2018; revised 27 April, 2018; accepted 4 May, 2018. *For correspondence. E-mail eboyd@ montana.edu; Tel. (+1) 406994 7046; Fax (+1) 4069944926. seconds (e.g., earthquakes) to days (e.g., temperature variations and diurnal cycling) to seasons (e.g., precipitation) (Hurwitz and Lowenstern, 2014). A common adaptive strategy for microorganisms that inhabit dynamic environments, such as hot springs, is to harbor flexibility in their metabolism (Kassen, 2002). Among characterized thermophilic organisms, crenarchaeotes may exhibit the most flexible of lifestyles as they relate to carbon and energy metabolism (Dworkin, 2006). For example, several members of the Sulfolobales, in particular those within the Acidianus genus, have been characterized as being facultatively anaerobic, facultatively autotrophic and capable of using a variety of complex organic and inorganic compounds to support their energy metabolism (Huber and Prangishvili, 2006; Huber and Stetter, 2006).

Common among all characterized members of the Acidianus genus is the ability to utilize elemental sulfur $\left(\mathrm{S}^{\circ}\right)$ as an electron donor and/or acceptor, regardless of their sensitivity to $\mathrm{O}_{2}$ and their mode of carbon metabolism (Huber and Stetter, 2015). Despite exhibiting an overall metabolically flexible lifestyle, however, several $S^{\circ}$ metabolizing thermophiles exhibit characteristics during growth on certain substrates that are more reflective of specialization. For example, the crenarchaotes Acidianus ambivalens (Sulfolobales; Zillig et al., 1986; Laska et al., 2003) and Stetteria hydrogenophila (Desulfurococcales; Jochimsen et al., 1997) were shown to be incapable of organoheterotrophic (i.e., organic energy and carbon source) growth via reduction of $S^{\circ}$, but exhibited an ability to grow autotrophically via reduction of $S^{\circ}$. Autotrophic growth with $S^{\circ}$ as oxidant was shown to be obligately dependent on hydrogen $\left(\mathrm{H}_{2}\right)$ as the electron donor. Potential reasons for the obligate requirement for $\mathrm{H}_{2}$ during $\mathrm{S}^{\circ}$ reduction in these strains were not further explored.

Acidianus is common in acidic, high-temperature, sulfur-rich hot spring environments (Huber and Stetter, 2015), including those in Yellowstone National Park (YNP), Wyoming, USA (Segerer et al., 1986; Inskeep et al., 2010; Hochstein et al., 2016). We previously isolated an Acidianus strain (strain DS80) from a sulfur-rich, acidic hot spring in YNP (Amenabar et al., 2017). Like other Acidianus strains (Segerer et al., 1986; Zillig et al., 1986; Plumb et al., 2007; Giaveno et al., 2013), strain DS80 displayed versatility in its energy metabolism 
involving $\mathrm{H}_{2}$ or $\mathrm{S}^{\circ}$ as electron donors and $\mathrm{S}^{\circ}$ or ferric iron $\left(\mathrm{Fe}^{3+}\right)$ as electron acceptors (Amenabar et al., 2017). The strain was also shown to be capable of aerobic autotrophic growth with $\mathrm{S}^{\circ}$ serving as electron donor and aerobic organoheterotrophic growth using a variety of substrates. Intriguingly, under anaerobic lithotrophic growth conditions, DS80 cells provided with $\mathrm{H}_{2} / \mathrm{Fe}^{3+} / \mathrm{S}^{\circ}$ utilized the $\mathrm{H}_{2} / \mathrm{S}^{\circ}$ redox couple rather than the $\mathrm{H}_{2} / \mathrm{Fe}^{3+}$ or $\mathrm{S}^{\circ} / \mathrm{Fe}^{3+}$ redox couples, despite the lower energy yield associated with the former (Amenabar et al., 2017). We suggested that the use of the $\mathrm{H}_{2} / \mathrm{S}^{\circ}$ redox couple was due to more thermodynamically efficient coupling of electron transfer reactions in an evolutionarily optimized membrane-bound [NiFe]-hydrogenase and membraneassociated sulfur reductase, which co-purify as a complex in A. ambivalens (Laska et al., 2003). Evolutionary optimization to efficiently couple electron transfer reactions between $\mathrm{H}_{2}$ and $\mathrm{S}^{\circ}$ in strain DS80, and potentially other strains (e.g., A. ambivalens and $S$. hydrogenophila), may lead to specificity in the source of reductant that can be used to reduce $S^{\circ}$ via the sulfur reductase complex. If true, this may explain why $S^{\circ}$ reducing $A$. ambivalens and S. hydrogenophila cells were shown to be obligately dependent on $\mathrm{H}_{2}$ as electron donor. In turn, such specificity may affect the carbon metabolism of $\mathrm{S}^{\circ}$ reducing cells, especially if organic compounds cannot be used as electron donors in energy metabolism.

In the present study, we aimed to test whether growth with $\mathrm{S}^{\circ}$ as an oxidant is limited to $\mathrm{H}_{2}$ as a reductant and, if so, what effect this might have on the carbon metabolism of the cell. To achieve this goal, we characterized the ability of alternative substrates (as carbon sources and/or electron donors) to support growth in DS80 cells provided with a variety of oxidants, including $\mathrm{S}^{\circ}, \mathrm{Fe}^{3+}$, or $\mathrm{O}_{2}$. Second, we aimed to determine whether $\mathrm{H}_{2}$ influenced the use of inorganic and organic carbon sources in cells grown with $\mathrm{S}^{\circ}, \mathrm{Fe}^{3+}$ or $\mathrm{O}_{2}$ as oxidant. Putative inorganic and organic carbon sources capable of supporting growth in strain DS80 were identified using genome reconstruction followed by homology-based informatics approaches. Physiological analyses were then used to examine carbon metabolism in cells provided with $\mathrm{S}^{\circ}, \mathrm{Fe}^{3+}$ or $\mathrm{O}_{2}$ in the presence or absence of $\mathrm{H}_{2}$. Results are discussed in the context of the role of electron acceptor availability in dictating the variety of electron donor and carbon sources that can support the growth of strain DS80. Moreover, the role of $\mathrm{H}_{2}$ in allowing heterotrophic growth (chemolithoheterotrophy) in cells reducing $\mathrm{S}^{\circ}$ is discussed, with an emphasis placed on biochemical mechanisms potentially explaining observed patterns of electron donor and carbon source usage with different electron acceptors in this and other thermophilic strains.

\section{Results}

Genomic prediction of electron donor, electron acceptor and carbon source usage

A partial genome for DS80 was reported previously (Amenabar et al., 2017) and was shown to code for sulfur reductase (Sre) and pilin proteins that might be involved in reduction of $\mathrm{S}^{\circ}$ and $\mathrm{Fe}^{3+}$ with $\mathrm{H}_{2}$ as electron donor and $\mathrm{CO}_{2}$ as a carbon source, respectively; c-type multiheme cytochromes putatively involved in $\mathrm{Fe}^{3+}$ reduction in bacteria (Myers and Myers, 1997; Leang et al., 2003) were not detected in the genome. Thus, the exact mechanism used by strain DS80 to reduce $\mathrm{Fe}^{3+}$ is unknown. The partial genome of DS80 also encodes proteins with homology to those that allow use of a variety of single carbon compounds as putative electron donors or carbon sources (Fig. 1). For example, a complement of genes encoding the majority (15 out of 16) of the enzymes involved in the hydroxypropionate-hydroxybutyrate pathway of $\mathrm{CO}_{2}$ fixation was identified in the DS80 genome, consistent with the ability of strain DS80 to grow with $\mathrm{CO}_{2}$ as the sole carbon source (Amenabar et al., 2017). The gene encoding for methylmalonyl-CoA epimerase was not detected in the genome. However, this enzyme is not required for this pathway to be functional (Berg et al., 2010b). A full suite of genes encoding a Nidependent carbon monoxide dehydrogenase $(\mathrm{CODH})$, an ' $\mathrm{H}$ '-type formate dehydrogenase $(\mathrm{FDH}-\mathrm{H})$ and a membrane bound [NiFe]-hydrogenase (Hyn) were also identified in the genome of DS80 (Supporting Information Fig. S1). Synteny in the genes coding for Hyn and Sre in the genomes of strain DS80 and $A$. ambivalens (Laska et al., 2003) suggest that a similar mechanism of coupling $\mathrm{H}_{2}$ oxidation with $\mathrm{S}^{\circ}$ reduction like that described for A. ambivalens (Laska et al., 2003) could be operational in strain DS80 (Fig. 1).

The DS80 genome was shown to encode several other enzymes putatively involved in sulfur metabolism, including a cytoplasmic sulfur oxygenase reductase (SOR) that has been shown or hypothesized to function in $\mathrm{S}^{\circ}$ oxidation in other members of the Acidianus genus such as Acidianus brierleyi (Emmel et al., 1986), A. ambivalens (Kletzin, 1989) and Acidianus tengchongensis (He et al., 2000). In addition to inorganic electron donors and carbon sources, the genome of DS80 coded for numerous sugar transporters and glycosidases suggesting an ability to utilize carbohydrates as carbon sources or energy substrates. Moreover, homologs of genes predicted to encode amino acid and oligopeptide transporters, as well as genes encoding proteolytic enzymes including endopeptidases, aminopeptidases and carboxypeptidases were identified in the DS80 genome, suggesting an ability for the cell to hydrolyze peptides and oxidize amino acids. Genes encoding a complete suite of homologs of 


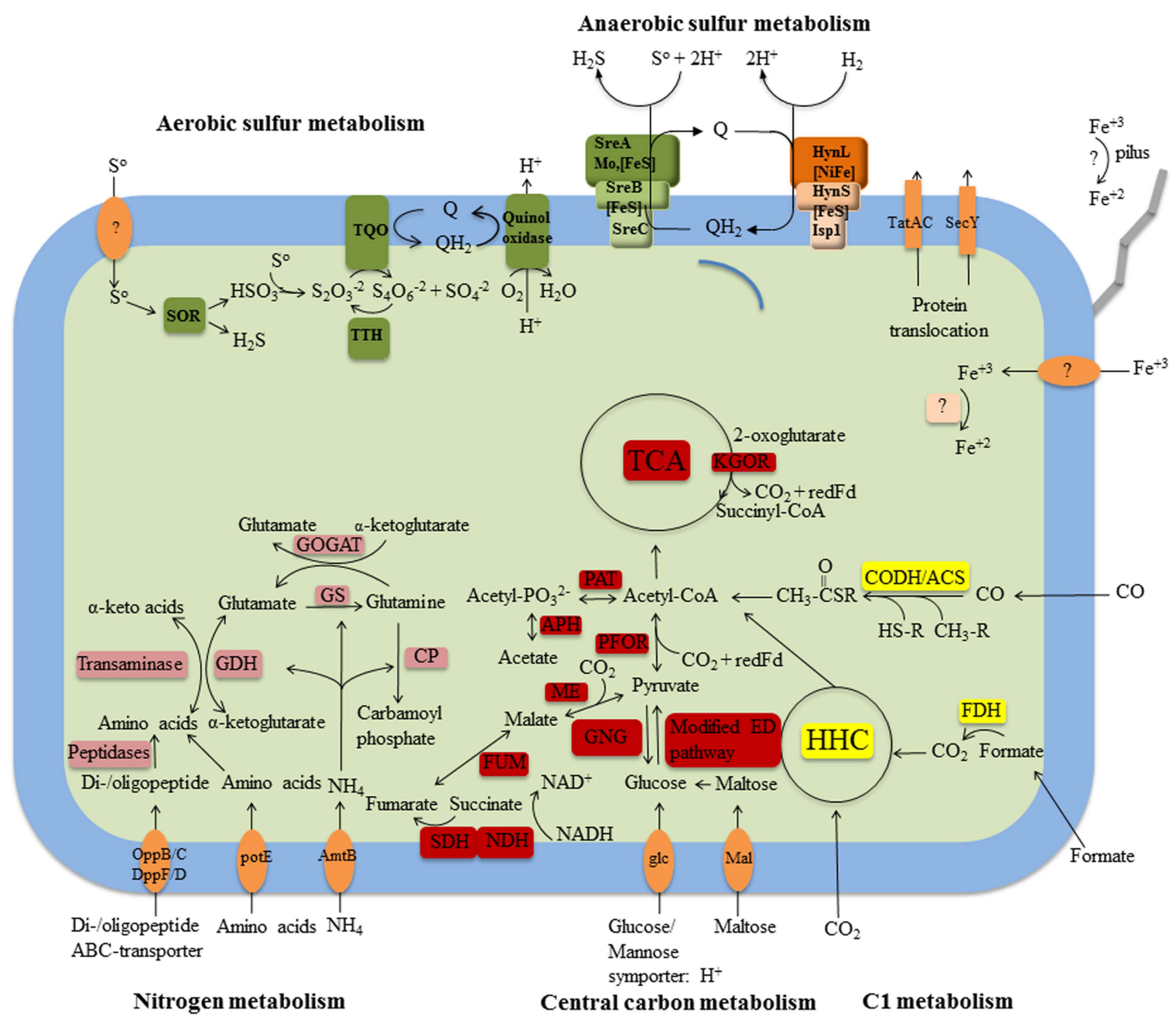

Fig. 1. Diagram of metabolic capabilities of Acidianus strain DS80.

Abbreviations: APH, acylphosphate phosphohydrolase; $\mathrm{CODH} / \mathrm{ACS}$, carbon monoxide dehydrogenase/acetyl-CoA synthase; $\mathrm{CP}$, carbamoyl phosphate synthetase; FDH, formate dehydrogenase; FUM, fumarate hydratase; GDH, glutamate dehydrogenase; GNC, gluconeogenesis; GOGAT, glutamate synthase; GS, glutamine synthetase; HHC, hydroxypropionate-hydroxybutyrate cycle; KGOR, 2-oxoglutarate ferredoxin oxidoreductase; ME, malic enzyme; NDH, NADH dehydrogenase; PAT, phosphate acetyltransferase; PFOR, pyruvate:ferredoxin oxidoreductase; Q, quinone; redFd, reduced ferredoxin; SDH, succinate dehydrogenase; SOR, sulfur oxygenase reductase; TQO, thiosulfate quinone oxidoreductase; TTH, tetrathionate hydrolase. Extracellular electron transport via pili has been hypothesized to be involved in iron reduction in Acidianus strain DS80 previously (Amenabar et al., 2017). The hypothetical model of $S^{\circ}$ oxidation and reduction were modified from Kletzin and colleagues (2004). Only those metabolic reactions and pathways that are the focus of this article are indicated. [Colour figure can be viewed at wileyonlinelibrary.com]

the tricarboxylic acid (TCA) cycle, gluconeogenesis and the non-phosphorylative Entner-Doudoroff pathway (Fig. 1 and Supporting Information Fig. S2) were also detected in the DS80 genome, suggesting an ability for this strain to utilize organic substrates during organotrophic metabolism. A homolog of the pyruvate ferredoxin oxidoreductase (PFOR), putatively involved in the carboxylation of acetyl-CoA to pyruvate (Furdui and Ragsdale, 2000), was also detected in the DS80 genome, consistent with the ability of strain DS80 to assimilate acetate through the gluconeogenic pathway (see below for more details). Other genes encoding for homologs of enzymes putatively involved in acetate assimilation such as those of the glyoxylate shunt (Kornberg and Krebs, 1957) or the ethylmalonyl-CoA pathway (Erb et al., 2007) were not detected in DS80 genome.

\section{Physiological examination of carbon source and electron donor usage}

To test genome-based predictions of the ability of DS80 to utilize a wide variety of substrates to support growth, cultures were provided with a range of inorganic $\left(\mathrm{CO}_{2}\right.$, $\mathrm{CO}$ ) and organic compounds (acetate, formate, glucose, fructose, galactose, mannose, lactose, maltose, sucrose, yeast extract, peptone and casamino acids) as carbon 
sources $\left(100 \% \mathrm{H}_{2}\right.$ headspace) or as carbon and energy sources (without $\mathrm{H}_{2}$ in the head space) with $\mathrm{S}^{\circ}, \mathrm{Fe}^{3+}$ and $\mathrm{O}_{2}$ as electron acceptors. Importantly, the presence of $\mathrm{H}_{2}$ in growth assays containing an organic carbon source does not necessarily guarantee that $\mathrm{H}_{2}$ is used as the sole electron donor or that these organic substrates are used solely as a carbon source. However, the comparison of growth in medium supplied with and without $\mathrm{H}_{2}$ helps to differentiate if these substrates can serve as a carbon source or a primary reductant. Substrate reduction and oxidation activities and the production of cells were monitored in these growth assays (Table 1).

Cells coupled the oxidation of numerous inorganic (i.e., $\mathrm{CO}$ ) and organic carbon sources (i.e., acetate, formate, glucose, galactose, mannose, lactose, maltose, yeast extract, peptone and casamino acids) to the reduction of $\mathrm{Fe}^{3+}$ to sustain growth under anaerobic conditions, regardless of whether $\mathrm{H}_{2}$ was provided to cultures. This indicates that these inorganic and organic substrates can be used as both a carbon source and as an electron donor. In contrast, when $\mathrm{S}^{\circ}$ served as electron acceptor (anaerobic conditions), these inorganic and organic carbon sources could only support growth if $\mathrm{H}_{2}$ was also provided in what can be described as chemolithoheterotrophic metabolism (i.e., inorganic energy source with an organic compound as the source of carbon). This indicates that $\mathrm{CO}$, formate, acetate, glucose, galactose, mannose, lactose, maltose, yeast extract, peptone and casamino acids can serve as a carbon source but not as the primary reductant during growth with $\mathrm{S}^{\circ}$ as electron acceptor. The addition of $\mathrm{CO}_{2}$ to cultures provided with these carbon sources

Table 1. Growth of Acidianus strain DS80 in base salts medium $\left(80^{\circ} \mathrm{C}\right.$; pH 3.0) with specified carbon sources when $\mathrm{S}^{\circ}, \mathrm{Fe}^{3+}$ or $\mathrm{O}_{2}$ served as electron acceptor.

\begin{tabular}{|c|c|c|c|c|c|}
\hline \multirow[b]{2}{*}{ Carbon source } & \multicolumn{2}{|l|}{$\mathrm{S}^{\circ}$} & \multicolumn{2}{|l|}{$\mathrm{Fe}^{3+}$} & \multirow{2}{*}{$\frac{\mathrm{O}_{2}}{\mathrm{H}_{2}(-)}$} \\
\hline & $\mathrm{H}_{2}(+)$ & $\mathrm{H}_{2}(-)$ & $\mathrm{H}_{2}(+)$ & $\mathrm{H}_{2}(-)$ & \\
\hline $\mathrm{CO}_{2}$ & + & $N / D$ & + & $N / D$ & $\mathrm{~N} / \mathrm{D}$ \\
\hline $\mathrm{CO}$ & + & - & + & + & $N / D$ \\
\hline Formate & + & - & + & + & + \\
\hline Acetate & + & - & + & + & + \\
\hline Glucose & + & - & + & + & + \\
\hline Fructose & - & - & - & - & - \\
\hline Galactose & + & - & + & + & + \\
\hline Mannose & + & - & + & + & + \\
\hline Lactose & + & - & + & + & + \\
\hline Maltose & + & - & + & + & + \\
\hline Sucrose & - & - & - & - & - \\
\hline Yeast extract & + & - & + & + & + \\
\hline Peptone & + & - & + & + & + \\
\hline Casamino acids & + & - & + & + & + \\
\hline
\end{tabular}

The ability for each carbon source to support growth was tested in the presence (+) and absence (-) of $\mathrm{H}_{2 \cdot}+$, growth [denotes whether a given growth condition supported a significant $(P<0.05)$ increase in the number of cells at any point during growth, when compared to the number of cells at time zero]; -, no growth; N/D, not determined. did not allow growth under $\mathrm{S}^{\circ}$ reducing conditions in the absence of $\mathrm{H}_{2}$ (Supporting Information Table S1), indicating that the lack of growth was not due to cells being obligate mixotrophs with respect to their carbon metabolism. Fructose and sucrose did not support growth of DS80 under any of the growth conditions tested. Most of the organic substrates tested could support growth under aerobic conditions, and growth under these conditions was not dependent on the presence of $\mathrm{H}_{2}$ (Table 1).

\section{Carbon assimilation and mineralization}

Growth experiments indicating that DS80 could not couple organotrophic metabolism with $\mathrm{S}^{\circ}$ reduction but could couple organotrophic metabolism to $\mathrm{Fe}^{3+}$ and $\mathrm{O}_{2}$ reduction prompted additional experiments using ${ }^{14} \mathrm{C}$ radiolabeled acetate to determine the ability of strain DS80 to assimilate and/or oxidize (mineralize) acetate with different electron acceptors. In cultures provided with ${ }^{14} \mathrm{C}$-acetate $/ \mathrm{H}_{2} / \mathrm{S}^{\circ}$, the density of cells, the amount of acetate assimilated and the concentration of total sulfide increased concurrently (Fig. 2A). ${ }^{14} \mathrm{CO}_{2}$ was not detected above background levels in the headspace of these cultures suggesting that if any acetate was mineralized to $\mathrm{CO}_{2}$, it was likely simultaneously assimilated into biomass. However, the data presented in Table 1 suggest that acetate is primarily used as a carbon source and not as the primary electron donor when $\mathrm{S}^{\circ}$ served as electron acceptor. Indeed, no evidence for acetate oxidation/mineralization or assimilation was observed in cultures without $\mathrm{H}_{2}$ provided with $\mathrm{S}^{\circ}$ as the terminal electron acceptor and acetate as the sole carbon and electron source (data not shown), consistent with growth assays indicating that this cultivation condition did not support growth.

In cultures provided with ${ }^{14} \mathrm{C}$-acetate/ $/ \mathrm{H}_{2} / \mathrm{Fe}^{3+}$, the cell density, the amount of acetate assimilated and the concentration of total $\mathrm{Fe}^{2+}$ increased concurrently (Fig. 2B). ${ }^{14} \mathrm{CO}_{2}$ was detected in the headspace indicating that acetate was also being oxidized/mineralized under this condition. However, cultures provided with $\mathrm{Fe}^{3+}$ as the terminal electron acceptor and acetate as a carbon and electron source (no added $\mathrm{H}_{2}$ ) had a significantly greater amount of ${ }^{14} \mathrm{CO}_{2}$ headspace than cultures provided with $\mathrm{H}_{2}$ (Fig. 2C). This indicates that $\mathrm{H}_{2}$ can serve as an additional source of reductant in $\mathrm{Fe}^{3+}$ reducing cells grown with acetate and/or that cells are simultaneously assimilating acetate and the $\mathrm{CO}_{2}$ released from acetate mineralization.

The cell yield per mol of $\mathrm{Fe}^{3+}$ reduced, calculated during log phase $(72-168 \mathrm{~h})$, when grown with ${ }^{14} \mathrm{C}$-acetate/ $\mathrm{H}_{2} /$ $\mathrm{Fe}^{3+}$, was 0.6 -fold lower than when cells were grown with acetate as the sole carbon and energy source (1.1 versus 1.8 cells per fmol $\mathrm{Fe}^{3+}$ reduced, respectively) $(P=0.04)$. This suggests that cells were more efficient at coupling energy metabolism with biomass synthesis when acetate 

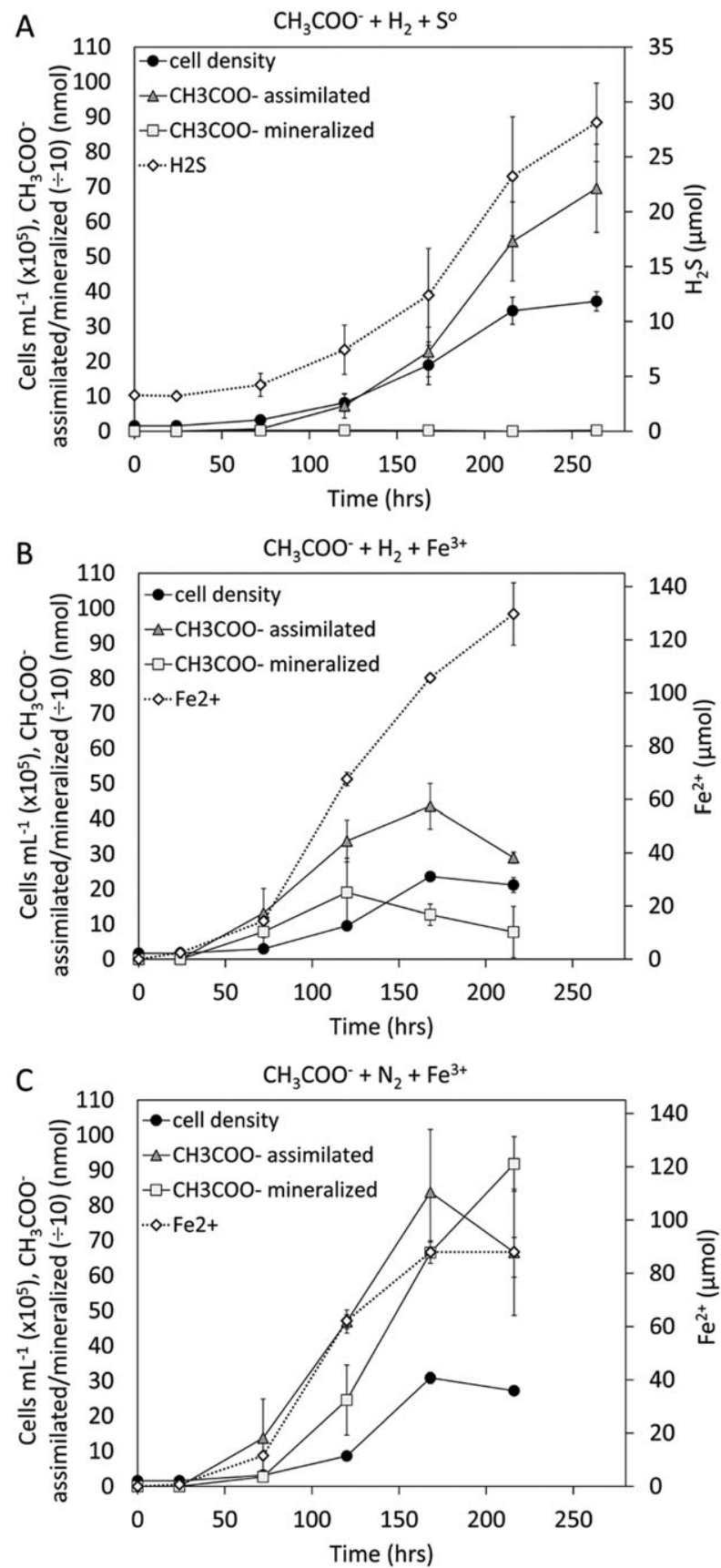

Fig. 2. Growth and substrate transformation activities of cultures of Acidianus strain DS80 provided with $\mathrm{H}_{2}$, acetate (a portion of the acetate provided was enriched in $1-\left[{ }^{14} \mathrm{C}\right]$ acetate) and $S^{\circ}(A), H_{2}$, acetate (a portion of the acetate provided was enriched in $1-\left[{ }^{14} \mathrm{C}\right]$ acetate) and $\mathrm{Fe}^{3+}$ [provided as $\left.\mathrm{Fe}_{2}\left(\mathrm{SO}_{4}\right)_{3}\right]$ (B) or with acetate (a portion of the acetate provided was enriched in $1-\left[{ }^{14} \mathrm{C}\right]$ acetate) and $\mathrm{Fe}^{3+}$ [provided as $\mathrm{Fe}_{2}\left(\mathrm{SO}_{4}\right)_{3}$ ] (C). No increase in cell density, acetate mineralization/assimilation activity or $\mathrm{S}^{\circ}$ reduction activity was observed when cultures were provided with only $S^{\circ}$ and acetate (data not shown). Error bars reflect the standard deviation of average measurements made on three replicate cultures.

served as both the energy and carbon source. The amount of $\mathrm{C}$ assimilated per cell in log phase cultures (72-168 h) when grown with ${ }^{14} \mathrm{C}$-acetate/ $/ \mathrm{H}_{2} / \mathrm{Fe}^{3+}$ $\left(0.3 \pm 0.1 \mathrm{fmol} C\right.$ cell $\left.^{-1}\right)$ was not significantly different $(P=0.36)$ than the amount observed when grown without $\mathrm{H}_{2}\left(0.5 \pm 0.2 \mathrm{fmol} \mathrm{C}\right.$ cell $\left.^{-1}\right)$. These data suggest that electrons recovered from $\mathrm{H}_{2}$ are involved in less efficient respiratory chains in DS80 than electrons from acetate under $\mathrm{Fe}^{3+}$ reducing conditions. The production of ${ }^{14} \mathrm{CO}_{2}$ in the headspace of ${ }^{14} \mathrm{C}$-acetate $/ \mathrm{H}_{2} / \mathrm{Fe}^{3+}$ grown cultures (Fig. 2B) suggests that this strain may be growing mixotrophically with respect to its energy metabolism when it is provided with acetate.

\section{Influence of acetate on DIC assimilation}

To explore the effects of acetate on DIC assimilation, DS80 cells were provided with ${ }^{14} \mathrm{CO}_{2} / \mathrm{H}_{2} / \mathrm{S}^{\circ}$ or ${ }^{14} \mathrm{CO}_{2} / \mathrm{H}_{2} /$ $\mathrm{Fe}^{3+}$ and these cultures were amended with different concentrations of nonisotopically enriched acetate (up to $200 \mu \mathrm{M})$. In cultures provided with $\mathrm{H}_{2} / \mathrm{S}^{\circ}$, the amount of DIC assimilated into biomass decreased systematically with higher concentrations of acetate, relative to unamended controls (Fig. 3A). However, the magnitude of the suppression of DIC assimilation was not proportional to the amount of acetate provided, in particular when cells were provided with $100 \mu \mathrm{M}$ or greater acetate. This indicates that acetate was not limiting growth and that cells were assimilating DIC in the presence of acetate. Moreover, despite evidence indicating that acetate suppresses DIC assimilation in cells provided with $\mathrm{H}_{2} / \mathrm{S}^{\circ}$ (Fig. $3 \mathrm{~A}$ ), amendment of cultures with acetate had no effect on the production of cells (Fig. 3B). This indicates that acetate, when provided at concentrations of $200 \mu \mathrm{M}$ or less, is not toxic to the cells due to internal acidification, as has been described for other thermoacidophiles (Urschel et al., 2016). Together, these results indicate that cells provided with $\mathrm{H}_{2} / \mathrm{S}^{\circ}$ are simultaneously using DIC and acetate to meet their carbon demands in what can be termed mixotrophy with respect to their carbon metabolism.

Like cells provided with ${ }^{14} \mathrm{CO}_{2} / \mathrm{H}_{2} / \mathrm{S}^{\circ}$, rates of DIC assimilation in cells provided with ${ }^{14} \mathrm{CO}_{2} / \mathrm{H}_{2} / \mathrm{Fe}^{3+}$ decreased systematically by amendment with higher concentrations of acetate (Fig. 3C). The magnitude of the suppression of DIC assimilation was not proportional to the amount of acetate provided, and amendment with acetate also did not influence the production of cells (Fig. 3D). Together, these observations indicate that cells provided with $\mathrm{H}_{2} / \mathrm{Fe}^{3+}$ are simultaneously using DIC and acetate to meet their carbon demands in what can be described as mixotrophy with respect to both their carbon and their energy metabolism.

\section{Influence of DIC on acetate assimilation and mineralization}

To explore the effects of DIC on acetate assimilation, DS80 cells were provided with ${ }^{14} \mathrm{C}$-acetate $/ \mathrm{H}_{2} / \mathrm{S}^{\circ}$ or 

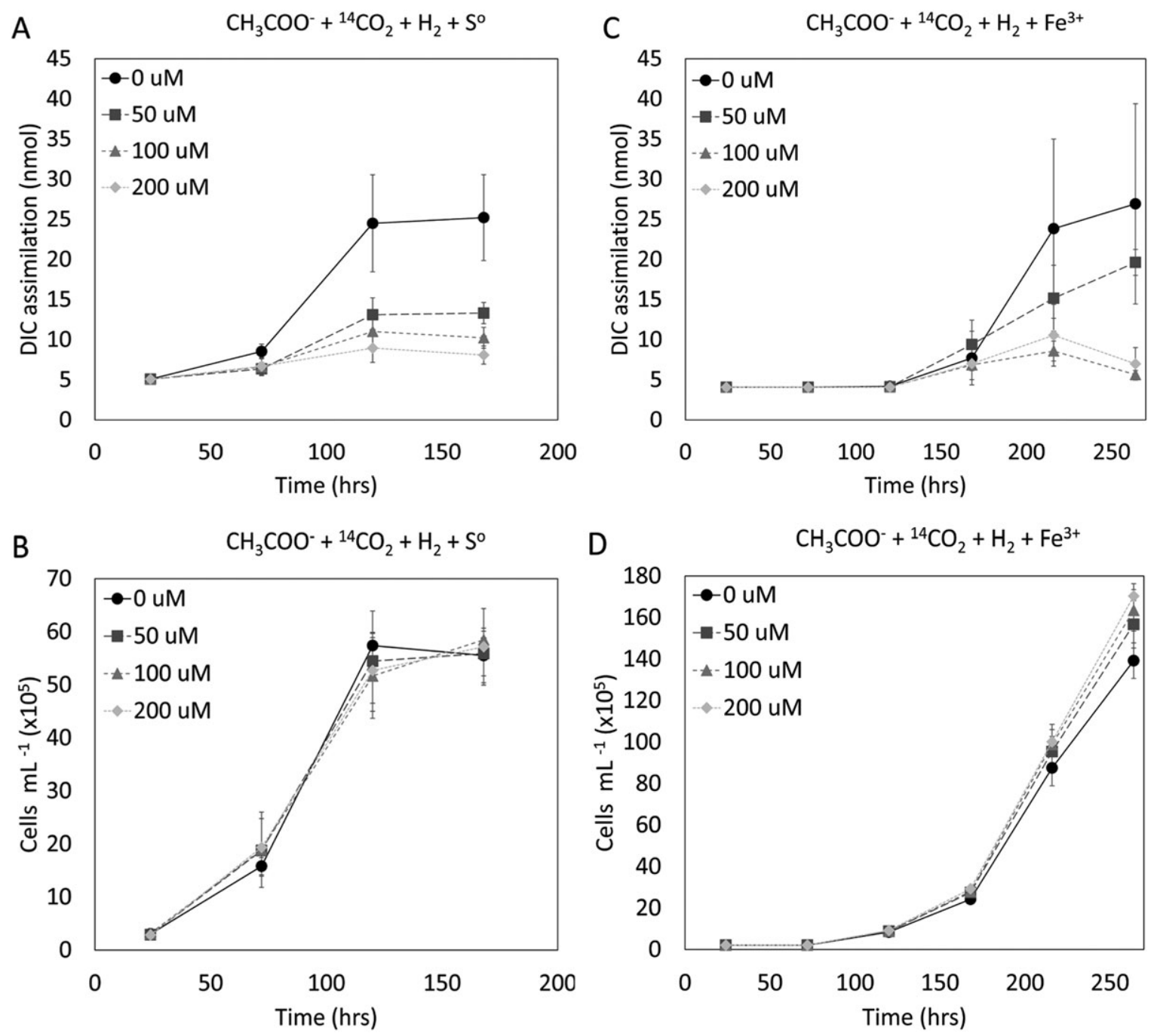

Fig. 3. DIC assimilation and the number of cells produced in cultures of Acidianus strain $\mathrm{DS} 80$ provided with $\mathrm{H}_{2}, \mathrm{~S}^{\circ}$ and $\mathrm{CO}_{2}(\mathrm{a}$ portion of the $\mathrm{CO}_{2}$ provided was enriched in ${ }^{14} \mathrm{C}$ ) ( $\mathrm{A}$ and $\mathrm{B}$, respectively) or $\mathrm{H}_{2}, \mathrm{Fe}^{3+}$ [provided as $\mathrm{Fe}_{2}\left(\mathrm{SO}_{4}\right)_{3}$ ] and $\mathrm{CO}_{2}\left(\mathrm{a}\right.$ portion of the $\mathrm{CO}_{2}$ provided was enriched in $\left.{ }^{14} \mathrm{C}\right)(\mathrm{C}$ and $\mathrm{D}$, respectively) amended with $0,50,100$ or $200 \mu \mathrm{M}$ acetate. Error bars reflect the standard deviation of average measurements made on three separate cultures.

${ }^{14} \mathrm{C}$-acetate/ $/ \mathrm{H}_{2} / \mathrm{Fe}^{3+}$ and these cultures were amended with nonisotopically enriched $\mathrm{CO}_{2}$. The addition of $\mathrm{CO}_{2}$ did not significantly affect the final number of cells produced at stationary phase in cultures provided with ${ }^{14} \mathrm{C}$-acetate $/ \mathrm{H}_{2} / \mathrm{S}^{\circ}$ (Fig. 4A), when compared to those not provided with $\mathrm{CO}_{2}\left(3.93 \times 10^{6}\right.$ versus $3.72 \times 10^{6}$ cells $\mathrm{ml}^{-1}$, respectively) $(P=0.28)$ (Fig. $\left.2 \mathrm{~A}\right)$. In contrast, the addition of $\mathrm{CO}_{2}$ to cultures provided with ${ }^{14} \mathrm{C}$-acetate/ $/ \mathrm{H}_{2} /$ $\mathrm{Fe}^{3+}$ (Fig. 4B) resulted in a $311 \%$ increase in the number of cells produced at stationary phase, when compared to cells provided with only ${ }^{14} \mathrm{C}$-acetate/ $\mathrm{H}_{2} / \mathrm{Fe}^{3+}\left(9.72 \times 10^{6}\right.$ versus $2.36 \times 10^{6}$ cells $\mathrm{ml}^{-1}$, respectively $(P<0.01)$ (Fig. 2B). At stationary phase, the ratio of acetate mineralized to that assimilated was $1: 4$ for ${ }^{14} \mathrm{C}$-acetate $/ \mathrm{H}_{2} / \mathrm{Fe}^{3+}$ grown cells in the absence of $\mathrm{CO}_{2}$ (Fig. 2B) versus 3:4 for cells grown in the presence of $\mathrm{CO}_{2}$ (Fig. 4B), which is likely due to a decreased reliance on acetate as the sole source of carbon (i.e., cells are fixing $\mathrm{CO}_{2}$ ). Consistent with this interpretation, ${ }^{14} \mathrm{C}$-acetate $/ \mathrm{H}_{2} / \mathrm{Fe}^{3+}$ grown cells provided with $\mathrm{CO}_{2}$ assimilated $0.7 \mathrm{fmol}$ of acetate per cell at stationary phase when compared to $3.7 \mathrm{fmol}$ of acetate per cell when ${ }^{14} \mathrm{C}$-acetate/ $/ \mathrm{H}_{2} / \mathrm{Fe}^{3+}$ grown cells were not provided with $\mathrm{CO}_{2}$. These observations confirm that strain DS80 is mixotrophic with respect to both its carbon and energy metabolism, when $\mathrm{Fe}^{3+}$ is provided as an electron acceptor. Moreover, ${ }^{14} \mathrm{C}$-acetate $/ \mathrm{H}_{2} / \mathrm{Fe}^{3+}$ grown cells provided with $\mathrm{CO}_{2}$ mineralized $25 \mathrm{fmol}$ of acetate per cell at stationary phase when compared to $50 \mathrm{fmol}$ of acetate mineralized per cell when ${ }^{14} \mathrm{C}$-acetate/ $\mathrm{H}_{2} / \mathrm{Fe}^{3+}$ grown cells were not provided with $\mathrm{CO}_{2}$. This may 

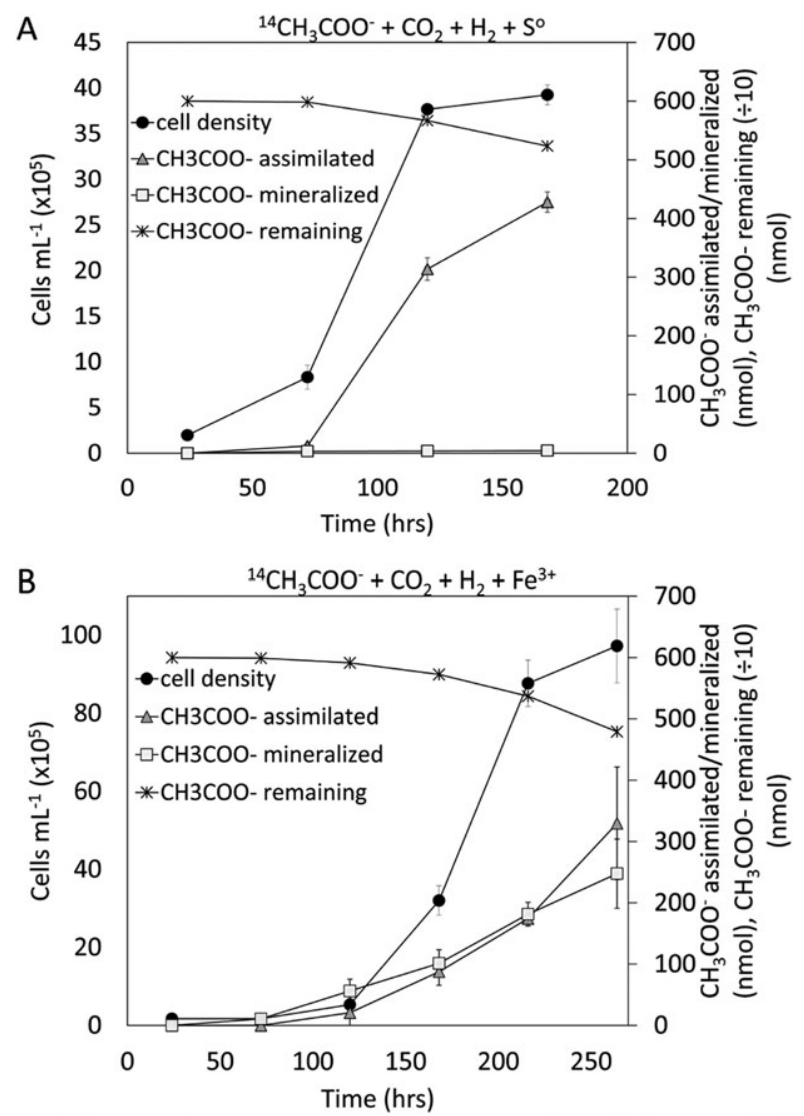

Fig. 4. Acetate assimilation and mineralization (a portion of the acetate provided was enriched in $1-\left[{ }^{14} \mathrm{C}\right]$ acetate) in the presence of $\mathrm{CO}_{2}$ (headspace of $20 / 80 \%$, vol/vol, $\mathrm{CO}_{2} / \mathrm{H}_{2}$ ) in cultures of Acidianus strain DS80 provided with $\mathrm{H}_{2}, \mathrm{~S}^{\circ}, \mathrm{CO}_{2}$ and $100 \mu \mathrm{M}$ total acetate (A) or with $\mathrm{H}_{2}, \mathrm{Fe}^{3+}$ [provided as $\left.\mathrm{Fe}_{2}\left(\mathrm{SO}_{4}\right)_{3}\right], \mathrm{CO}_{2}$ and $100 \mu \mathrm{M}$ acetate (B). Error bars reflect the standard deviation of average measurements made on three separate cultures. The concentration of acetate remaining in culture medium (residual acetate) was calculated by subtracting the total amount of acetate that was used (mineralized and assimilated) from the total amount of acetate added (mass balance).

suggest that a portion of the acetate oxidized in cells grown with ${ }^{14} \mathrm{C}$-acetate $/ \mathrm{H}_{2} / \mathrm{Fe}^{3+}$ is to generate $\mathrm{CO}_{2}$ as a substrate for gluconeogenic carboxylation reactions.

\section{Discussion}

Genomic and physiological characterization indicates that Acidianus strain DS80, like other Acidianus strains (Segerer et al., 1986; Zillig et al., 1986; Bettstetter et al., 2003; He et al., 2004; Yoshida et al., 2006; Plumb et al., 2007; Giaveno et al., 2013), exhibits flexibility in its metabolism at the level of electron donors, electron acceptors and carbon sources capable of supporting its metabolism. However, flexibility in the energy and carbon metabolism of strain DS80 was shown to have its limitations. For example, strain DS80 was capable of growing mixotrophically with respect to its carbon metabolism (simultaneous assimilation of $\mathrm{CO}_{2}$ and organic carbon) and energy metabolism (simultaneous oxidation of $\mathrm{H}_{2}$ and acetate) when $\mathrm{Fe}^{3+}$ served as electron acceptor; mixotrophic growth was not rigorously examined when $\mathrm{O}_{2}$ served as electron acceptor. In contrast to growth with $\mathrm{Fe}^{3+}$ as electron acceptor, cells provided with $\mathrm{S}^{\circ}$ as electron acceptor could only grow mixotrophically with respect to carbon metabolism (assimilation of $\mathrm{CO}_{2}$ and acetate) and this activity was obligately dependent on $\mathrm{H}_{2}$ as an electron donor. This observation is like those made for $S$. hydrogenophila and for A. ambivalens, both of which were shown to be obligately dependent on $\mathrm{H}_{2}$ as electron donor during $\mathrm{S}^{\circ}$ dependent growth (Zillig et al., 1986; Jochimsen et al., 1997).

Despite genomic data indicating an apparent ability to utilize a range of organic substrates as electron and carbon requirements, organic substrates cannot serve as the sole electron donor when $\mathrm{S}^{\circ}$ served as electron acceptor. Rather, $\mathrm{H}_{2}$ is required as an electron donor in acetate oxidizing, $S^{\circ}$ reducing cells. It is likely that cells grown with acetate $/ \mathrm{H}_{2} / \mathrm{S}^{\circ}$ or acetate $/ \mathrm{H}_{2} / \mathrm{Fe}^{3+}$ (or other organic compounds) are oxidizing at least a portion of the acetate, since $\mathrm{CO}_{2}$ is needed to drive the carboxylation of acetyl CoA to pyruvate via the activity of PFOR prior to entry into the gluconeogenic pathway during chemolithoheterotrophic growth (Supporting Information Fig. S2). A low potential electron donor such as ferredoxin $(F d)$ is also required to drive the reductive carboxylation of acetyl-CoA to pyruvate by the PFOR enzyme (Furdui and Ragsdale, 2000). Since the redox potential of some Fds are close to that of the $\mathrm{H}_{2}$ electrode (Buckel and Thauer, 2013), it is possible that $\mathrm{Fd}$ is reduced by the activity of the [NiFe]hydrogenase encoded in the DS80 genome. Indeed, a protein encoded in an open reading frame [Integrated Microbial Genomes (IMG) gene ID: 2690452627] adjacent to the large subunit of [NiFe]-hydrogenase is homologous to a small Rieske Fd from A. ambivalens (Genbank accession number: CAC86888). Biochemical characterization of a recombinant form of this $\mathrm{Fd}$ from $A$. ambivalens indicates that the protein harbors a high potential $(+170 \mathrm{mV})$ Rieske-like iron sulfur (FeS) cluster (Kletzin et al., 2005). This indicates that the $\mathrm{FeS}$ cluster in this $\mathrm{Fd}$ may be reduced by $\mathrm{H}_{2}(\sim-420 \mathrm{mV}$; Buckel and Thauer, 2013) via [NiFe]-hydrogenase but is unlikely to be of low enough potential to carboxylate acetyl CoA to yield pyruvate $(-500$ $\mathrm{mV}$ ) (Thauer et al., 1977).

Other reactions have been shown to produce reduced Fd under chemo(litho)heterotrophic growth conditions to support PFOR activity. One of these involves the oxidative decarboxylation of 2-oxoglutarate to form succinyl-CoA, $\mathrm{CO}_{2}$ and reduced $\mathrm{Fd}$ via the activity of 2-oxoglutarate ferredoxin oxidoreductase (KGOR) (Mai and Adams, 1996). Two copies of the alpha and beta subunits of the KGOR were detected in the genome of 
A. hospitalis (You et al., 2011) and in the partial genome of strain DS80 (IMG gene IDs: 2690452354/2690452355 and 2690452739/2690452738). The presence of genes encoding for homologs of the KGOR in DS80 could potentially explain how reduced $\mathrm{Fd}$ and $\mathrm{CO}_{2}$ are being generated as substrates for PFOR during chemolithoheterotrophic growth with acetate $/ \mathrm{H}_{2} / \mathrm{S}^{\circ}$ or acetate $/ \mathrm{H}_{2} / \mathrm{Fe}^{3+}$ (or other organic compounds).

While reduced Fd is likely required during chemolithoheterotrophic growth in strain DS80, reduced Fd might not be required for autotrophic growth. This conjecture is based on previous reports suggesting that under autotrophic conditions, gluconeogenesis in aerobic Sulfolobales does not proceed via acetyl-CoA, since acetyl-CoA was shown to not be assimilated via the Fd-dependent carboxylation activity of pyruvate synthase (Berg et al., 2010b; Estelmann et al., 2011). Rather, succinyl-CoA, which is withdrawn from the carbon fixation cycle via oxidation to malate or oxaloacetate, serves as a precursor for biosynthesis/gluconeogenesis in aerobic Sulfolobales (Berg et al., 2010b; Estelmann et al., 2011). Pyruvate and phosphoenolpyruvate (PEP) formation likely proceeds from these two $\mathrm{C} 4$ compounds via the activities of the malic enzyme and PEP carboxykinase respectively (Berg et al., 2010b; Estelmann et al., 2011). While these pathways for $\mathrm{Fd}$ independent generation of pyruvate and PEP as substrates for gluconeogenesis have been described in aerobic Sulfolobales (Berg et al., 2010b; Estelmann et al., 2011), it has also been shown that under anaerobic autotrophic conditions other Sulfolobales such as Stygiolobus azoricus do not use PFOR to generate pyruvate from acetyl-CoA. Rather, these cells appear to use the malic enzyme to generate pyruvate from malate as input to the gluconeogenesis pathway (Berg et al., 2010a) similar to what has been reported for Sulfolobales grown aerobically. Like $S$. azoricus, the genome of strain DS80 encodes for a homolog of the malic enzyme (IMG gene ID: 2690453198) suggesting potential involvement of this enzyme in Fd-independent pyruvate formation and gluconeogenesis during anaerobic, autotrophic growth.

The glyoxylate shunt (Kornberg and Krebs, 1957) or the ethylmalonyl-CoA (Erb et al., 2007) pathways are not involved in acetate assimilation in DS80 since homologs of the enzymes comprising these pathways were not detected in the DS80 genome. Thus, we suggest that the lack of detectable $\mathrm{CO}_{2}$ in cultures provided with acetate/ $\mathrm{H}_{2} / \mathrm{S}^{\circ}$ was due to its use as a substrate in carboxylation reactions (Fig. 2A). Evidence in potential support of this conjecture comes from the observation that cells are capable of simultaneously assimilating both acetate and $\mathrm{CO}_{2}$ when $\mathrm{S}^{\circ}$ serves as oxidant (Fig. $3 \mathrm{~A}$ ). Since addition of $\mathrm{CO}_{2}$ to acetate/S $\mathrm{S}^{\circ}$ grown cultures also did not allow growth under what would be considered mixotrophic conditions (Table S1), we conclude that acetate cannot serve as the primary electron donor in $\mathrm{S}^{\circ}$ grown cells. Rather, acetate is primarily used as a carbon source with $\mathrm{H}_{2}$ serving as the primary electron donor to cells growing autotrophically or heterotrophically with $\mathrm{S}^{\circ}$ as oxidant. The dependence on $\mathrm{H}_{2}$ as the primary electron donor during organotrophic growth with $\mathrm{S}^{\circ}$ as electron acceptor can be described as chemolithoheterotrophic metabolism, which has been shown (albeit not necessarily defined as such) in sulfur oxidizing Bacteria (King, 2007; Ghosh and Dam, 2009) and sulfur-reducing Archaea (Jochimsen et al., 1997).

Several possible explanations exist for why members of the genus Acidianus may not be able to respire $\mathrm{S}^{\circ}$ using the organic compounds tested here. The first involves the cellular localization of the Sre complex, which may constrain delivery of electrons to the complex due to specificity of the Sre for electron carriers. Based on genomic inferences, respiration of $\mathrm{S}^{\circ}$ with $\mathrm{H}_{2}$ in hyperthermophiles, including Thermoproteus tenax (Siebers et al., 2011), A. ambivalens (Laska et al., 2003) and presumably DS80 (see Supporting information) is mediated by a short electron transfer chain comprising a membrane-associated [NiFe]-hydrogenase and a membrane-associated (Sre1) complex linked by a quinone cycle (Laska et al., 2003) (Fig. 5A). Respiration with $\mathrm{S}^{\circ}$ as electron acceptor in these strains is like the membrane-bound respiratory system found in mesophilic $\mathrm{S}$ /polysulfide reducing bacteria such as Wolinella succinogenes (Hedderich et al., 1998). The Sre1 operon in T. tenax, A. ambivalens and Acidianus strain DS80 codes for five subunits (ABCDE), with the alpha subunit (SreA) coding for a twin arginine motif indicating that it is localized on the external side of the plasma membrane. However, the genome of $T$. tenax also codes for a second Sre operon (Sre2) that includes only three subunits (ABC); none of the subunits code for twin-arginine motifs indicating a cytoplasmic orientation of this membrane bound complex (Siebers et al., 2011) (Fig. 5B), which may influence the source of reductants that can be used to reduce this complex.

Unlike $A$. ambivalens and strain DS80, T. tenax can respire $S^{\circ}$ using organic compounds, which are oxidized via the oxidative TCA cycle. During organotrophic growth, $T$. tenax conserves energy via a membrane-bound electron transport chain with $S^{\circ}$ as the terminal electron acceptor (Siebers et al., 2004, 2011). In addition to organotrophic growth coupled to $S^{\circ}$ reduction, Thermoproteus strain CP80 can grow autotrophically with $\mathrm{H}_{2}$ and $\mathrm{S}^{\circ}$ (Urschel et al., 2016); the genome of CP80 encodes both cytoplasmic (Sre2) and extracellular oriented (Sre1) Sre complexes. We suggest that differences in the orientation of the Sre complex (extracellular versus cytoplasmic) allow the use of electron donors present in the cytosol by 
A A. ambivalens

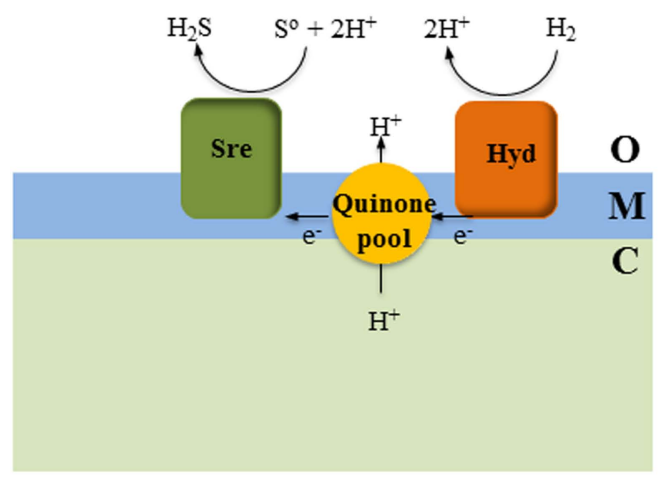

$\mathrm{C}$

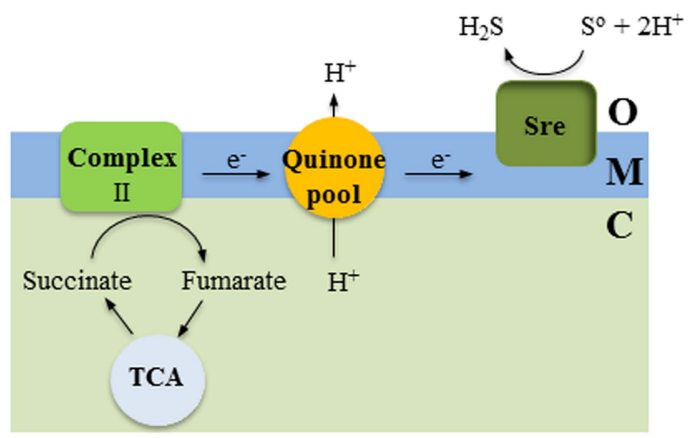

B T. tenax

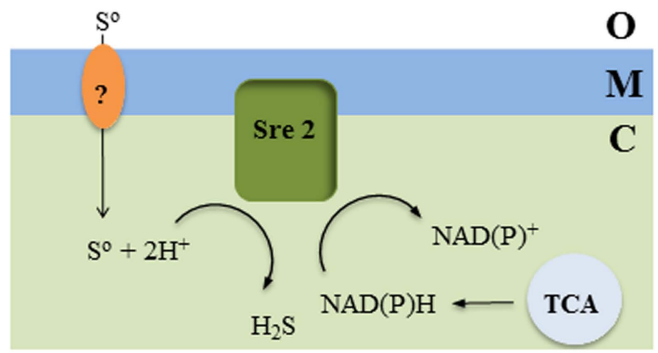

$\mathrm{D}$

A. aeolicus

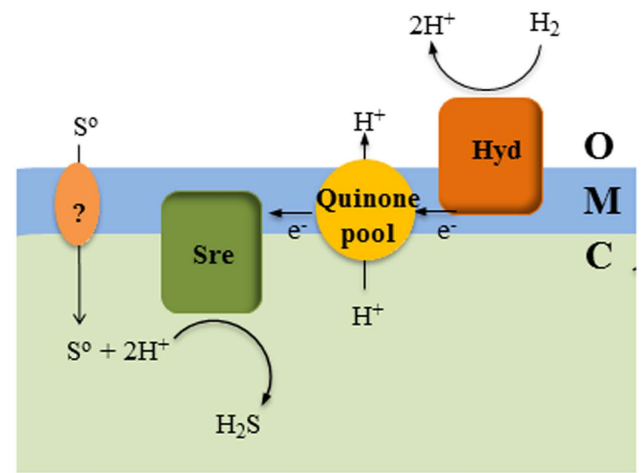

Fig. 5. Diagrams of proposed pathways for $\mathrm{S}^{\circ}$ reduction with $\mathrm{H}_{2}$ or organic carbon substrates as sources of reductant. Abbreviations: Sre, sulfur reductase; Hyd, group 1 [NiFe]-hydrogenase; TCA, tricarboxylic acid cycle; O, outside of cell; M, membrane; C, cytosol. [Colour figure can be viewed at wileyonlinelibrary.com]

Sre2, including $\mathrm{NAD}(\mathrm{P}) \mathrm{H}$ produced from the TCA cycle. This enables electrons derived from oxidation of organic carbon to be coupled to the reduction of $\mathrm{S}^{\circ}$ (Fig. 5B).

A second possible explanation for the difference in the ability to respire $S^{\circ}$ with organic electron donors in the Thermoproteales (i.e., Thermoproteus spp.) but not the Sulfolabales (i.e., Acidianus spp.) is in the types of co-factors involved in electron transfer to $\mathrm{S}^{\circ}$. For example, it has been suggested that succinate dehydrogenase (complex II) in T. tenax (Siebers et al., 2004, 2011) is involved in the reduction of $\mathrm{S}^{\circ}$ when organic compounds serve as electron donor. Succinate dehydrogenase is a membrane-bound component of the TCA cycle and can provide an entry point for electrons derived from the oxidation of succinate into the membrane quinone pool, which can then be used to reduce $\mathrm{S}^{\circ}$ via the membrane bound Sre (Siebers et al., 2004, 2011) (Fig. 5C). Like T. tenax, members of the Sulfolobales, including DS80 and $A$. ambivalens, code for succinate dehydrogenase (Lemos et al., 2001; Schafer et al., 2002). However, asisolated succinate dehydrogenase from $A$. ambivalens was shown to contain bound caldariellaquinone (Lemos et al., 2001; Schafer et al., 2002), suggesting that electrons are transferred during succinate oxidation to this specific quinone pool. Biochemical studies indicate that caldariellaquinone cannot be used to reduce membranebound Sre in A. ambivalens (Laska et al., 2003). Rather, the specific quinone that is used to reduce Sre in A. ambivalens is sulfolobusquinone (Laska et al., 2003), which differs structurally from caldariellaquinone in that it lacks a mercaptan side chain (Collins and Langworthy, 1983; Thurl et al., 1986; Elling et al., 2016).

While caldariellaquinone is produced by $A$. ambivalens, it is usually only found in the membranes of aerobically grown cells and not $S^{\circ}$ grown cells (Laska et al., 2003). Similarly, caldariellaquinone is the predominant quinone in aerobically grown Sulfolobus solfataricus cells; sulfolobusquinone is detected in greater amounts in S. solfataricus cells grown under progressively $\mathrm{O}_{2}$ limited conditions (Nicolaus et al., 1992). Thus, differences in the specificity of the membrane bound Sre complex for sulfolobusquinone versus caldariellaquinone may be another reason why DS80, and Acidianus strains in general, cannot link organic carbon oxidation to the reduction of $\mathrm{S}^{\circ}$. Further 
evidence that this phenomenon is due to the specificity of Sre for sulfolobusquinone rather than for the [NiFe]hydrogenase for specific quinones comes from the fact that electrons from $\mathrm{H}_{2}$ (presumably generated via the sole [NiFe]-hydrogenase homolog encoded in the DS80 genome) can be used to reduce $\mathrm{Fe}^{3+}$, albeit with a low efficiency of energy conservation as indicated by a 0.6-fold reduction in cell yields when $\mathrm{H}_{2}$ is provided to acetate/ $\mathrm{Fe}^{3}$

+ grown cells when compared to those not provided $\mathrm{H}_{2}$.

The ability of strain DS80 to grow with organic substrates as sole electron donors when respiring $\mathrm{Fe}^{3+}$ or $\mathrm{O}_{2}$ (Table 1) but not with other oxidants (i.e., $\mathrm{S}^{\circ}$ ) is a potentially widespread phenomenon among hyperthermophiles. For example, Ferroglobus placidus cannot utilize acetate as the sole electron donor when either nitrate or thiosulfate were provided as electron acceptor (Hafenbradl et al., 1996). However, acetate was shown to be capable of supporting growth when iron was provided as the electron acceptor (Tor et al., 2001). These observations are consistent with those from DS80 and support the notion that the metabolic versatility of carbon metabolism in hyperthermophilic microorganisms may be expanded when iron is provided as an electron acceptor (Vargas et al., 1998). These observations also suggest the possibility that the mechanisms for iron reduction in these taxa are not necessarily specific, which may allow for co-factors or oxidoreductase complexes and their associated co-factors to non-specifically reduce iron. The results shown here indicate that providing $\mathrm{H}_{2}$ as electron donor can also allow for use of alternative electron acceptors (i.e., $\mathrm{S}^{\circ}$ ) when organic carbon sources are available to these cells. It is not known if the addition of $\mathrm{H}_{2}$ would allow heterotrophic growth in nitrate or thiosulfate grown $F$. placidus cells.

The greater amount of acetate mineralized by $\mathrm{Fe}^{3+}$ reducing DS80 cells when acetate served as electron donor when compared to acetate/ $\mathrm{H}_{2}$ as electron donors suggests that the addition of $\mathrm{H}_{2}$ decreases the flux of low potential electrons derived from acetate into electron transport chains and a potential diversion of a portion of this acetate away from oxidation via the TCA cycle and toward gluconeogenesis. Indeed, observed growth yields of DS80 with $\mathrm{Fe}^{3+}$ when acetate was used as carbon and energy source when compared with growth yields when both $\mathrm{H}_{2}$ and acetate were present, were higher. Here, less efficient electron transfers involving the $\mathrm{H}_{2} / \mathrm{Fe}^{3+}$ redox couple, additional energetic costs associated with reduction of acetate during gluconeogenesis pathways and additional energetic costs associated with synthesis of the enzymes necessary to metabolize $\mathrm{H}_{2}$ and to perform gluconeogenesis could influence the overall efficiency of coupling energy metabolism to biomass synthesis (Furdui and Ragsdale, 2000; Amenabar et al., 2017).
The metabolic flexibility displayed by strain DS80 appears to be a shared characteristic among members of the Acidianus genus (Table S2), which is comprised of physiologically versatile members that can grow as facultative anaerobes or facultative autotrophs with the ability to oxidize or reduce $\mathrm{S}^{\circ}$ depending on $\mathrm{O}_{2}$ availability (Huber and Stetter, 2015). Like DS80 (Amenabar et al., 2017), some Acidianus species have also been shown to respire $\mathrm{Fe}^{3+}$ with $\mathrm{H}_{2}$ or $\mathrm{S}^{\circ}$ (Yoshida et al., 2006; Giaveno et al., 2013). This generalist strategy, in addition to the observation that $\mathrm{H}_{2}$ enables the use of organic carbon sources in DS80 cells respiring $\mathrm{S}^{\circ}$ (chemolithoheterotrophic metabolism), may contribute to a broadening of ecological niche space, both spatially and temporally, and therefore provide a competitive advantage to these cells in dynamic environments where the availability of carbon sources, electron donors and electron acceptors varies (Hurwitz and Lowenstern, 2014). To this end, we suggest that electron acceptor availability alters the carbon and energy metabolism of strain DS80, with $\mathrm{H}_{2}$ being obligate for growth when $\mathrm{S}^{\circ}$ serves as electron acceptor regardless if cells are growing autotrophically or heterotrophically. Based on work presented here, and the work of others (Jochimsen et al., 1997; King, 2007; Ghosh and Dam, 2009), we suggest that chemolithoheterotrophic metabolism may be much more common in nature than is currently recognized.

In summary, the data presented here suggest that the use of electron donors and carbon sources can be influenced by the types of electron acceptors available (e.g., $\mathrm{Fe}^{3+}$ versus $\mathrm{S}^{\circ}$ reduction) and the presence or absence of $\mathrm{H}_{2}$ (i.e., in the case of $\mathrm{S}^{\circ}$ reduction). These data also clearly indicate that predictions of the metabolism of a cell based on the presence or absence of genes or geochemical/thermodynamic data indicating energetic favorability of a given redox reaction may not play out in natural systems. We suggest the need to more completely characterize the physiology of microbial cells and to integrate this with genomic and thermodynamic data to more accurately predict the distribution of microorganisms and their metabolic activities in natural systems. Future studies are needed to investigate the metabolic capabilities of strain DS80 when grown chemolithoheterotrophically or mixotrophically under microaerophilic conditions.

\section{Experimental procedures}

\section{Culture conditions}

Acidianus strain DS80, previously isolated from 'Dragon Spring', Yellowstone National Park, Wyoming (Amenabar et al., 2017), was cultivated in anoxic base salts medium containing $\mathrm{NH}_{4} \mathrm{Cl} \quad\left(0.33 \mathrm{~g} \mathrm{I}^{-1}\right), \quad \mathrm{KCl} \quad\left(0.33 \mathrm{~g} \mathrm{I}^{-1}\right)$, $\mathrm{CaCl}_{2} \cdot 2 \mathrm{H}_{2} \mathrm{O} \quad\left(0.33 \mathrm{~g} \mathrm{I}^{-1}\right), \quad \mathrm{MgCl}_{2} \cdot 6 \mathrm{H}_{2} \mathrm{O} \quad\left(0.33 \mathrm{~g} \mathrm{I}^{-1}\right)$ and 
$\mathrm{KH}_{2} \mathrm{PO}_{4}\left(0.33 \mathrm{~g} \mathrm{I}^{-1}\right)$. The $\mathrm{pH}$ of the medium was adjusted to 3.0 with concentrated hydrochloric acid. Fifty-five $\mathrm{mL}$ of medium was dispensed into $160 \mathrm{ml}$ serum bottles and was subjected to autoclave sterilization. Following autoclave sterilization and while still hot $\left(\sim 90^{\circ} \mathrm{C}\right)$, filter-sterilized Wolfe's vitamins ( $1 \mathrm{ml} \mathrm{l}^{-1}$ final concentration), filter sterilized SL-10 trace metals ( $1 \mathrm{ml} \mathrm{l}^{-1}$ final concentration) and $\mathrm{S}^{\circ}\left(5 \mathrm{~g} \mathrm{l}^{-1}\right.$ final concentration; sterilized by baking at $100^{\circ} \mathrm{C}$ for $24 \mathrm{~h}$ ) or filter sterilized ferric iron in the form of $\mathrm{Fe}_{2}\left(\mathrm{SO}_{4}\right)_{3} \cdot \mathrm{H}_{2} \mathrm{O}\left(3.7 \mathrm{~g} \mathrm{I}^{-1}\right)$ were added. The bottles and their contents were deoxygenated by purging with sterile nitrogen $\left(\mathrm{N}_{2}\right)$ gas passed over heated $\left(210^{\circ} \mathrm{C}\right)$ and $\mathrm{H}_{2}$ reduced copper shavings. The serum bottles were sealed with butyl rubber stoppers and heated to $80^{\circ} \mathrm{C}$ prior to the replacement of the headspace with $80: 20 \%$ $\mathrm{H}_{2}: \mathrm{CO}_{2}$, unless otherwise specified. All growth experiments were conducted at $80^{\circ} \mathrm{C}$ in medium with a pH of 3.0.

\section{Isolation of genomic DNA and sequencing}

Biomass for DNA extraction was concentrated via centrifugation $\left(14,000 \times \mathrm{g}, 20 \mathrm{~min}, 4^{\circ} \mathrm{C}\right)$ from a single $55 \mathrm{ml}$ autotrophically grown culture provided with $\mathrm{H}_{2}$ and $\mathrm{S}^{\circ}$ as electron donor and acceptor, respectively. The cell pellet was re-suspended in $1 \mathrm{ml}$ of sterile base salts medium and carbon disulfide $\left(\mathrm{CS}_{2}\right)$ was added to solubilize and partition $S^{\circ}$ into the organic phase to improve the recovery of DNA, as has been described previously (Boyd et al., 2007). $\mathrm{CS}_{2}$ was added to a final concentration of $10 \%(\mathrm{vol} / \mathrm{vol})$, and following phase separation, the aqueous phase was collected and concentrated by centrifugation $\left(14,000 \times g, 20 \mathrm{~min}, 4^{\circ} \mathrm{C}\right)$. Genomic DNA was extracted from the cell pellet using a modified phenolchloroform extraction procedure. Cells were first resuspended in $150 \mathrm{mM}$ Tris- $\mathrm{HCl}$ buffer $(\mathrm{pH}$ 7.5) containing $15 \mathrm{mM}$ EDTA ( $\mathrm{pH}$ 8.0) and then were subjected to three cycles of sonication (1 min each) on ice. Lysozyme was added to the extract to a final concentration of $1 \mathrm{mg} \mathrm{ml}^{-1}$, and the extract was incubated at $37^{\circ} \mathrm{C}$ for $30 \mathrm{~min}$. Following incubation, proteinase $\mathrm{K}\left(200 \mu \mathrm{g} \mathrm{ml}^{-1}\right.$ final concentration) and sodium dodecyl sulfate ( $1 \%$ final concentration) were added to the extract and the extract was incubated at $50^{\circ} \mathrm{C}$ for $30 \mathrm{~min}$. Cell debris was removed by centrifugation $(9000 \times g$ for $20 \mathrm{~min}$ ), and the resultant clarified phase was extracted with two volumes of phenol/chloroform and subjected to centrifugation $(14,000 \times \mathrm{g}, 10 \mathrm{~min}$, $4^{\circ} \mathrm{C}$ ). The soluble phase was again collected and extracted with two volumes of chloroform/isoamyl alcohol (24:1) and centrifuged $\left(14,000 \times g, 10 \mathrm{~min}, 4^{\circ} \mathrm{C}\right)$. Following centrifugation, the soluble phase was collected and DNA was precipitated from this fraction by adding two volumes of $100 \%$ ethanol, followed by incubation at $-20^{\circ} \mathrm{C}$ for $12 \mathrm{~h}$ and centrifugation $\left(14,000 \times \mathrm{g}, 10 \mathrm{~min}, 4^{\circ} \mathrm{C}\right)$ (Sambrook and Russell, 2001). The pellet was collected, dried in a laminar flow hood and re-suspended in $50 \mu \mathrm{l}$ of molecular grade water. The concentration of DNA in the extract was determined using a Qubit 2.0 Fluorimeter (Invitrogen, Carlsbad, CA, USA) and a Qubit dsDNA HS Assay kit (Molecular Probes, Eugene, OR, USA).

Total genomic DNA was sequenced at the Genomics Core Facility at the University of Wisconsin-Madison using the Illumina MiSeq platform and the $2 \times 300$ bp v3 sequencing kit. Paired-end DNA fragments were prepared according to the manufacturer's protocol. Illumina reads were processed, assembled and analysed using the protocols described in the supporting online information. Details of the genome assembly statistics, percent coverage and relationships with other available Acidianus genomes at the level of genome composition and phylogeny are provided in the supplemental online information.

\section{Physiological characterization}

Organic compounds that support growth of strain DS80 when $\mathrm{S}^{\circ}$ or $\mathrm{Fe}^{3+}$ served as terminal electron acceptor were evaluated in anoxic base salts medium, prepared as described earlier. Putative carbon sources capable of supporting growth were identified based on analysis of the DS80 genome (supplemental online information). Glucose, fructose, galactose, mannose, lactose, maltose, sucrose, yeast extract, peptone and casamino acids were added to anoxic base salts medium to achieve a final concentration of $0.1 \%(\mathrm{wt} / \mathrm{vol})$. Sodium formate and sodium acetate were added to base salts medium to achieve a final concentration of $200 \mu \mathrm{M}$, since previous studies have shown these organic acids to be toxic to acidophiles at concentrations higher than $200 \mu \mathrm{M}$ (Urschel et al., 2016). All carbon sources were tested for their ability to serve as a carbon source $\left(100 \% \mathrm{H}_{2}\right.$ headspace) (lithoheterotrophy) or as a carbon and electron donor (100\% $\mathrm{N}_{2}$ headspace) (organoheterotrophy). The ability of strain DS80 to grow with carbon monoxide (CO) as a carbon source $\left(90: 10 \% \mathrm{H}_{2}: \mathrm{CO}\right.$ headspace) or as a carbon and electron donor $\left(90: 10 \% \mathrm{~N}_{2}\right.$ : $\left.\mathrm{CO}\right)$ was also examined. The ability of the specified organic compounds to support mixotrophic growth, with respect to carbon metabolism, was evaluated as described above using an $80: 20 \% \mathrm{~N}_{2}: \mathrm{CO}_{2}$ headspace. The ability of strain DS80 to grow organoheterotrophically with these different carbon sources when $\mathrm{O}_{2}$ served as terminal electron acceptor (serum bottle headspace was air) was also evaluated in cultures grown on a rotary shaker $(100 \mathrm{rpm})$ at $80^{\circ} \mathrm{C}$. The convention used to report experimental conditions for each growth assay throughout the text is carbon source/electron donor/electron acceptor in that order.

Growth and activity of strain DS80 with different carbon sources in the presence of various electron donors and acceptors were quantified in terms of cell density and 
production of total sulfide [( $\left.\mathrm{S}^{2-}\right)$; proxy for $\mathrm{S}^{\circ}$ reduction)] or ferrous iron $\left[\left(\mathrm{Fe}^{2+}\right)\right.$; proxy for $\mathrm{Fe}^{3+}$ reduction], as previously described (Amenabar et al., 2017). Aerobic cultures were monitored based only on cell density. Triplicate measurements (technical replicates) were made on each of the replicate cultures (biological replicates), and these were averaged for each culture. The results presented represent the average and standard deviation of the triplicate biological cultures

\section{Carbon assimilation and mineralization}

The amount of acetate assimilated into cellular biomass or mineralized and released as $\mathrm{CO}_{2}$ was determined in cultures provided with $\mathrm{S}^{\circ}$ or $\mathrm{Fe}^{3+}$ as terminal electron acceptor, in the presence or absence of $\mathrm{H}_{2}$. Briefly, $160 \mathrm{ml}$ serum bottles containing $55 \mathrm{ml}$ of base salts medium (described above) and $\mathrm{S}^{\circ}$ or $\mathrm{Fe}^{3+}$ with a $100 \%$ $\mathrm{H}_{2}$ or $100 \% \mathrm{~N}_{2}$ headspace was amended with acetate to a final concentration of $100 \mu \mathrm{M}$ [45:1 ratio of unlabeled acetate to $1-\left[{ }^{14} \mathrm{C}\right]$ sodium acetate $\left.\left(\mathrm{CH}_{3}^{14} \mathrm{COONa}\right)\right]$. Each assay received a total of $5 \mu \mathrm{Ci}$ of $1-\left[{ }^{14} \mathrm{C}\right]$-acetate. At each time point, a $2 \mathrm{ml}$ subsample of culture and a $1 \mathrm{ml}$ subsample of gas was removed from each vial for use in determining the amount of $1-\left[{ }^{14} \mathrm{C}\right]$-acetate assimilated into biomass or mineralized as $\mathrm{CO}_{2}$, using scintillation counting as previously described (Urschel et al., 2016). The concentration of $\mathrm{CO}_{2}$ that was present in the headspace was measured. The concentration of dissolved $\mathrm{CO}_{2}$ was assumed to be negligible due to the acidity of the medium. Three $\mathrm{ml}$ of sterile $\mathrm{N}_{2}$ or $\mathrm{H}_{2}$ (depending on the cultivation condition) was added to each vial at each sampling interval to maintain atmospheric pressure in the vials. Conversion of the assimilation or mineralization of $1-\left[{ }^{14} \mathrm{C}\right]$-labeled acetate to the assimilation or mineralization of total acetate (unlabeled plus labeled) was performed as previously described (Urschel et al., 2016).

\section{Influence of acetate on the assimilation of dissolved} inorganic carbon (DIC)

The amount of DIC assimilated into cellular biomass was determined in cultures of DS80 provided with $\mathrm{S}^{\circ}$ or $\mathrm{Fe}^{3+}$ as terminal electron acceptor in the presence of different concentrations of acetate. One hundred sixty milliliter serum bottles containing $55 \mathrm{ml}$ of base salts medium and $\mathrm{S}^{\circ}$ or $\mathrm{Fe}^{3+}$ with an $80: 20 \% \mathrm{H}_{2}: \mathrm{CO}_{2}$ headspace (described earlier) were amended with a total of $5 \mu \mathrm{Ci}$ of $\left[{ }^{14} \mathrm{C}\right]$-bicarbonate and with $0,50,100$ or $200 \mu \mathrm{M}$ unlabeled acetate. Cultures were inoculated, and the influence of acetate on the assimilation of ${ }^{14} \mathrm{CO}_{2}$ into biomass was determined as previously described (Urschel et al., 2016).
Influence of DIC on the assimilation and mineralization of acetate

The amount of acetate assimilated into cellular biomass was determined in cultures provided with $\mathrm{S}^{\circ}$ or $\mathrm{Fe}^{3+}$ as terminal electron acceptor in the presence or absence of added $\mathrm{CO}_{2}$. One hundred sixty milliliter serum bottles containing $55 \mathrm{ml}$ of base salts medium and $\mathrm{S}^{\circ}$ or $\mathrm{Fe}^{3+}$ with an $80: 20 \% \quad \mathrm{H}_{2}: \mathrm{CO}_{2}$ headspace (described earlier) were amended with a total of $5 \mu \mathrm{Ci}$ of $1-\left[{ }^{14} \mathrm{C}\right]$-acetate and unlabeled acetate to achieve a final concentration of $100 \mu \mathrm{M}$. Cultures were inoculated, and the influence of $\mathrm{CO}_{2}$ on the assimilation/mineralization of $1-\left[{ }^{14} \mathrm{C}\right]$ acetate was determined as previously described (Urschel et al., 2016).

\section{Statistical analyses}

Two tailed Student's $t$-tests were used to evaluate the statistical significance $(P<0.05)$ of differences between datasets and were conducted in Microsoft Excel.

\section{Acknowledgements}

This work was supported by the NASA Exobiology and Evolutionary Biology program (NNX13Al11G) to ESB. The NASA Astrobiology Institute is supported by grant number NNA15BB02A to ESB. MJA acknowledges support from the CONICYT Becas-Chile Scholarship program.

\section{References}

Amenabar, M.J., Shock, E.L., Roden, E.E., Peters, J.W., and Boyd, E.S. (2017) Microbial substrate preference dictated by energy demand rather than supply. Nat Geosci 10: 577-581.

Berg, I.A., Ramos-Vera, W.H., Petri, A., Huber, H., and Fuchs, G. (2010) Study of the distribution of autotrophic $\mathrm{CO}_{2}$ fixation cycles in Crenarchaeota. Microbiology 156: 256-269.

Berg, I.A., Kockelkorn, D., Ramos-Vera, W.H., Say, R.F., Zarzycki, J., Hugler, M., et al. (2010) Autotrophic carbon fixation in Archaea. Nat Rev Microbiol 8: 447-460.

Bettstetter, M., Peng, X., Garrett, R.A., and Prangishvili, D. (2003) AFV1, a novel virus infecting hyperthermophilic archaea of the genus Acidianus. Virology 315: 68-79.

Boyd, E.S., Jackson, R.A., Encarnacion, G., Zahn, J.A., Beard, T., Leavitt, W.D., et al. (2007) Isolation, characterization, and ecology of sulfur-respiring Crenarchaea inhabiting acid-sulfate-chloride-containing geothermal springs in Yellowstone National Park. Appl Environ Microbiol 73: 6669-6677.

Buckel, W., and Thauer, R.K. (2013) Energy conservation via electron bifurcating ferredoxin reduction and proto$\mathrm{n} / \mathrm{Na}+$ translocating ferredoxin oxidation. Biochim Biophy Acta Bioenerg 1827: 94-113. 
Collins, M.D., and Langworthy, T.A. (1983) Respiratory quinone composition of some acidophilic bacteria. Syst Appl Microbiol 4: 295-304.

Dworkin, M. (ed) (2006) Bacteria: Firmicutes, Cyanobacteria. New York, NY: Springer.

Elling, F.J., Becker, K.W., Könneke, M., Schröder, J.M., Kellermann, M.Y., Thomm, M., and Hinrichs, K.-U. (2016) Respiratory quinones in Archaea: phylogenetic distribution and application as biomarkers in the marine environment. Environ Microbiol 18: 692-707.

Emmel, T., Sand, W., Konig, W.A., and Bock, E. (1986) Evidence for the existence of a sulfur oxygenase in Sulfolobus brierleyi. J Gen Microbiol 132: 3415-3420.

Erb, T.J., Berg, I.A., Brecht, V., Muller, M., Fuchs, G., and Alber, B.E. (2007) Synthesis of C-5-dicarboxylic acids from C-2-units involving crotonyl-CoA carboxylase/reductase: the ethylmalonyl-CoA pathway. Proc Natl Acad Sci USA 104: 10631-10636.

Estelmann, S., Hugler, M., Eisenreich, W., Werner, K., Berg, I.A., Ramos-Vera, W.H., et al. (2011) Labeling and enzyme studies of the central carbon metabolism in Metallosphaera sedula. J Bacteriol 193: 1191-1200.

Furdui, C., and Ragsdale, S.W. (2000) The role of pyruvate ferredoxin oxidoreductase in pyruvate synthesis during autotrophic growth by the Wood-Ljungdahl pathway. $J$ Biol Chem 275: 28494-28499.

Ghosh, W., and Dam, B. (2009) Biochemistry and molecular biology of lithotrophic sulfur oxidation by taxonomically and ecologically diverse bacteria and archaea. FEMS Microbiol Rev 33: 999-1043.

Giaveno, M.A., Urbieta, M.S., Ulloa, J.R., Toril, E.G., and Donati, E.R. (2013) Physiologic versatility and growth flexibility as the main characteristics of a novel thermoacidophilic Acidianus strain isolated from Copahue Geothermal Area in Argentina. Microbial Ecol 65: 336-346.

Hafenbradl, D., Keller, M., Dirmeier, R., Rachel, R., Roßnagel, P., Burggraf, S., et al. (1996) Ferroglobus placidus gen nov, $\mathrm{sp}$ nov, a novel hyperthermophilic archaeum that oxidizes $\mathrm{Fe}^{2+}$ at neutral $\mathrm{pH}$ under anoxic conditions. Arch Microbiol 166: 308-314.

He, Z.G., Zhong, H.F., and Li, Y.Q. (2004) Acidianus tengchongensis sp nov., a new species of acidothermophilic Archaeon isolated from an acidothermal spring. Curr Microbiol 48: 159-163.

He, Z.G., Li, Y.Q., Zhou, P.J., and Liu, S.J. (2000) Cloning and heterologous expression of a sulfur oxygenase/reductase gene from the thermoacidophilic archaeon Acidianus sp. S5 in Escherichia coli. FEMS Microbiol Lett 193: 217-221.

Hedderich, R., Klimmek, O., Kroger, A., Dirmeier, R., Keller, M., and Stetter, K.O. (1998) Anaerobic respiration with elemental sulfur and with disulfides. FEMS Microbiol Rev 22: 353-381.

Hochstein, R.A., Amenabar, M.J., Munson-McGee, J.H., Boyd, E.S., and Young, M.J. (2016) Acidianus tailed spindle virus: a new archaeal large tailed spindle virus discovered by culture-independent methods. $J$ Virol 90: 3458-3468.

Huber, H., and Prangishvili, D. (2006) Sulfolobales. In The Prokaryotes. Dworkin, M., Falkow, S., Rosenberg, E., Schleifer, K.-H., and Stackebrandt, E. (eds). New York: Springer-Verlag, pp. 23-51.
Huber, H., and Stetter, K.O. (2006) Desulfurococcales. In The Prokaryotes. Dworkin, M., Falkow, S., Rosenberg, E., Schleifer, K.-H., and Stackebrandt, E. (eds). New York: Springer-Verlag, pp. 52-68.

Huber, H., and Stetter, K.O. (2015) Acidianus. In The Prokaryotes. Rosenberg, E., DeLong, E.F., Lory, S., Stackebrandt, E., and Thompson, F. (eds). Berlin: Springer-Verlag, pp. 1-5.

Hurwitz, S., and Lowenstern, J.B. (2014) Dynamics of the Yellowstone hydrothermal system. Rev Geophys 52: 375-411.

Inskeep, W.P., Rusch, D.B., Jay, Z.J., Herrgard, M.J., Kozubal, M.A., Richardson, T.H., et al. (2010) Metagenomes from high-temperature chemotrophic systems reveal geochemical controls on microbial community structure and function. PLoS One 5: e9773.

Jochimsen, B., Peinemann-Simon, S., Völker, H., Stüben, D., Botz, R., Stoffers, P., et al. (1997) Stetteria hydrogenophila, gen. nov. and sp. nov., a novel mixotrophic sulfurdependent crenarchaeote isolated from Milos, Greece. Extremophiles 1: 67-73.

Kassen, R. (2002) The experimental evolution of specialists, generalists, and the maintenance of diversity. $J$ Evol Biol 15: 173-190.

King, G.M. (2007) Chemolithotrohic bacteria: distributions, functions and significance in volcanic environments. Microbes Environ 22: 309-319.

Kletzin, A. (1989) Coupled enzymatic production of sulfite, thiosulfate, and hydrogen-sulfide from sulfur - purification and properties of a sulfur oxygenase reductase from the facultatively anaerobic archaebacterium Desulfurolobus ambivalens. J Bact 171: 1638-1643.

Kletzin, A., Urich, T., Muller, F., Bandeiras, T.M., and Gomes, C.M. (2004) Dissimilatory oxidation and reduction of elemental sulfur in thermophilic archaea. J Bioenerg Biomembr 36: 77-91.

Kletzin, A., Ferreira, A.S., Hechler, T., Bandeiras, T.M., Teixeira, M., and Gomes, C.M. (2005) A Rieske ferredoxin typifying a subtype within Rieske proteins: spectroscopic, biochemical and stability studies. FEBS Lett 579: 1020-1026.

Kornberg, H.L., and Krebs, H.A. (1957) Synthesis of cell constituents from C2-units by a modified tricarboxylic acid cycle. Nature 179: 988-991.

Laska, S., Lottspeich, F., and Kletzin, A. (2003) Membrane-bound hydrogenase and sulfur reductase of the hyperthermophilic and acidophilic archaeon Acidianus ambivalens. Microbiology 149: 2357-2371.

Leang, C., Coppi, M.V., and Lovley, D.R. (2003) OmcB, a c-type polyheme cytochrome, involved in $\mathrm{Fe}(\mathrm{III})$ reduction in Geobacter sulfurreducens. J Bacteriol 185: 2096-2103.

Lemos, R.S., Gomes, C.M., and Teixeira, M. (2001) Acidianus ambivalens complex II typifies a novel family of succinate dehydrogenases. Biochem Biophys Res Commun 281: $141-150$.

Mai, X.H., and Adams, M.W.W. (1996) Characterization of a fourth type of 2-keto acid-oxidizing enzyme from a hyperthermophilic archaeon: 2-ketoglutarate ferredoxin oxidoreductase from Thermococcus litoralis. $J$ Bacteriol 178: 5890-5896. 
Myers, C.R., and Myers, J.M. (1997) Cloning and sequence of cymA a gene encoding a tetraheme cytochrome $\mathrm{C}$ required for reduction of iron(III), fumarate, and nitrate by Shewanella putrefaciens MR-1. J Bacteriol 179: 1143-1152.

Nicolaus, B., Trincone, A., Lama, L., Palmieri, G., and Gambacorta, A. (1992) Quinone composition in Sulfolobus solfataricus grown under different conditions. Syst Appl Microbiol 15: 18-20.

Plumb, J.J., Haddad, C.M., Gibson, J.A.E., and Franzmann, P.D. (2007) Acidianus sulfidivorans sp. nov., an extremely acidophilic, thermophilic archaeon isolated from a solfatara on Lihir Island, Papua New Guinea, and emendation of the genus description. Int J Syst Evol Microbiol 57: 1418-1423.

Sambrook, J., and Russell, D.W. (2001) Molecular Cloning: A Laboratory Manual, 3rd ed. New York: Cold Spring Harbor Laboratory Press.

Schafer, G., Anemuller, S., and Moll, R. (2002) Archaeal complex II: 'classical' and 'non-classical' succinate: quinone reductases with unusual features. Biochim Biophys Acta 1553: 57-73.

Segerer, A., Neuner, A., Kristjansson, J.K., and Stetter, K.O. (1986) Acidianus infernus gen. nov., sp. nov., and Acidianus brierleyi Comb. nov.: Facultatively aerobic, extremely acidophilic thermophilic sulfur-metabolizing Archaebacteria. Int J Syst Evol Microbiol 36: 559-564.

Siebers, B., Tjaden, B., Michalke, K., Dorr, C., Ahmed, H., Zaparty, M., et al. (2004) Reconstruction of the central carbohydrate metabolism of Thermoproteus tenax by use of genomic and biochemical data. $J$ Bacteriol 186: 2179-2194.

Siebers, B., Zaparty, M., Raddatz, G., Tjaden, B., Albers, S. V., Bell, S.D., et al. (2011) The complete genome sequence of Thermoproteus tenax: a physiologically versatile member of the Crenarchaeota. PLos One 6: e24222.

Thauer, R.K., Jungermann, K., and Decker, K. (1977) Energy-conservation in chemotropic anaerobic bacteria. Bacteriol Rev 41: 100-180.

Thurl, S., Witke, W., Buhrow, I., and Schafer, W. (1986) Quinones from archaebacteria, II. Different types of quinones from sulphur-dependent archaebacteria. Biol Chem Hoppe Seyler 367: 191-197.

Tor, J.M., Kashefi, K., and Lovley, D.R. (2001) Acetate oxidation coupled to $\mathrm{Fe}(\mathrm{III})$ reduction in hyperthermophilic microorganisms. Appl Environ Microbiol 67: 1363-1365.

Urschel, M.R., Hamilton, T.L., Roden, E.E., and Boyd, E.S. (2016) Substrate preference, uptake kinetics and bioenergetics in a facultatively autotrophic, thermoacidophilic crenarchaeote. FEMS Microbiol Ecol 92: fiw069.

Vargas, M., Kashefi, K., Blunt-Harris, E.L., and Lovley, D.R. (1998) Microbiological evidence for $\mathrm{Fe}(\mathrm{III})$ reduction on early Earth. Nature 395: 65-67.

Yoshida, N., Nakasato, M., Ohmura, N., Ando, A., Saiki, H., Ishii, M., and Igarashi, Y. (2006) Acidianus manzaensis sp nov., a novel thermoacidophilic Archaeon growing autotrophically by the oxidation of $\mathrm{H}_{2}$ with the reduction of $\mathrm{Fe}^{3+}$. Curr Microbiol 53: 406-411.

You, X.Y., Liu, C., Wang, S.Y., Jiang, C.Y., Shah, S.A., Prangishvili, D., et al. (2011) Genomic analysis of
Acidianus hospitalis W1 a host for studying crenarchaeal virus and plasmid life cycles. Extremophiles 15: 487-497.

Zillig, W., Yeats, S., Holz, I., Böck, A., Rettenberger, M., Gropp, F., and Simon, G. (1986) Desulfurolobus ambivalens, gen. nov., sp. nov., an autotrophic archaebacterium facultatively oxidizing or reducing sulfur. Syst Appl Microbiol 8: 197-203.

\section{Supporting Information}

Additional Supporting Information may be found in the online version of this article at the publisher's web-site:

Table S1. Growth of Acidianus strain DS80 in base salts medium $\left(80^{\circ} \mathrm{C}\right.$; $\left.\mathrm{pH} 3.0\right)$ with specified substrates as energy/ carbon sources when $\mathrm{S}^{\circ}$ served as electron acceptor. The ability for each carbon source to support growth was tested in the absence (-) of $\mathrm{H}_{2}$ and in the presence (+) of $20 \% \mathrm{CO}_{2}$.

Table S2. Comparison of metabolic characteristics among characterized Acidianus strains, as compiled from the specified literature references.

Fig. S1. Gene clusters encoding the [NiFe]-hydrogenase (hyn) and the sulfur reductase complex (sre) in Acidianus strain DS80. The ruler demarcates base pair positions, arrows indicate ORFs, RR indicates a conserved twinarginine motif and the tat cluster encodes proteins required for the twin-arginine protein translocation pathway (TAT).

Fig. S2. Gluconeogenesis and glucose degradation via a nonphosphorylative Entner-Doudoroff (ED) pathway.

DHAP, dihydroxyacetone phosphate; ENO, enolase; FBPA/ ase, fructose bisphosphate aldolase/phosphatase; GAD, gluconate dehydratase; GADH, glyceraldehyde dehydrogenase; GAPDH, glyceraldehyde-3-phosphate dehydrogenase; GDH, glucose dehydrogenase; GK, glycerate kinase; GLac, gluconolactonase; KDGA, 2-keto-3-deoxy-gluconate aldolase; PEPS, phosphoenolpyruvate synthetase; PFOR, pyruvate: ferredoxin oxidoreductase; PGAM, phosphoglycerate mutase; PGI, glucose-6-phosphate isomerase; PGK, phosphoglycerate kinase; PK, pyruvate kinase. Oxidative reactions are indicated in red, and reductive reactions are indicated in blue.

Fig. S3. Quality assessment via GC content of the Acidianus strain DS80 genome assembly.

Left panel shows average GC content of contigs calculated over a nonoverlapping sliding window of 5000 base pairs. The right panel shows the size of each genomic contig as a function of its deviation from the mean GC of the entire assembly. The red lines denote the expected deviation from the mean using a $95 \%$ confidence interval.

Fig. S4. Phylogenetic placement of Acidianus strain DS80 within the Sulfolobales order.

The Maximum Likelihood tree was constructed using a concatenation of 104 phylogenetic marker genes for a total of 30 archaeal genomes. All nodes shown exhibited bootstraps of $100 \%$ except for one node where the bootstrap value is indicated. Scale bar shows expected number of substitutions/site. Pyrobaculum islandicum was specified as an outgroup for the Sulfolobales genomes. 
Fig. S5. Average amino acid identity (AAI) of proteins encoded in the Acidianus strain DS80 genome when compared to the genome of Acidianus hospitalis W1. The top panel represents the percent identity while the bottom panel represents the bit score distribution.

Fig. S6. Average nucleotide identity (ANI) of the genome of Acidianus strain DS80 when compared to the genome of Acidianus hospitalis W1. The top panel represents the percent identity while the bottom panel represents the bit score distribution.
Fig. S7. Complete genome mapping between the Acidianus hospitalis W1 genome and 133 contigs generated from the sequencing of the genome of Acidianus strain DS80. Here, the orange strip (right) represents the genome from A. hospitalis W1 while the green strip (left) represents the 133 contigs. Colored links represent regions of high similarity as obtained from BLASTn. The red links represent the regions that were $>90 \%$ identical, green links represent regions that were between 80 and $90 \%$ identical, and blue links represent regions that were between 70 and $80 \%$ identical. 